DOI: $10.19195 / 2084-5065.44 .4$

\title{
Security measures in combating document falsifiers
}

\author{
RAFAL CIEŚla \\ Department of Forensic Sciences \\ Faculty of Law, Administration and Economics \\ University of Wrocław, Poland
}

A document is usually associated with an official letter outlining rights and obligations. It is normally made in writing, either handwritten or printed. It constitutes evidence in legal proceedings, authenticated with a signature, confirming veracity of the document itself or veracity of any circumstances stated in the document, including the identity of a given person, e.g. an identity card or a passport. A document is also a written record confirming an act in law constituting evidence and serving the same purposes ${ }^{1}$. The word 'document' comes from the Latin word "documentum", i.e. a person's intent resulting in the emergence of concrete legal circumstances.

The notion of the document is very important in all areas of law, even though its understanding varies and so far no uniform definition has been formulated, even in such closely related areas as substantive penal law, law of criminal proceedings and forensic science. An ambiguous definition of the document from the glossary of statutory notions ${ }^{2}$ in the

1 R. Cieśla, Technical Examination of Documents. Within the Scope of Polish Evidence Law, Wrocław 2006, pp. 34-52; L. Koźmiński, Dokument jako ślad kryminalistyczny, Piła 2010, p. 6.

2 Art. 115(14) Act 6 June 1997 with subsequent amendments, (Dz.U. of 1997 No. 88, item 553 with subsequent amendments). 
Penal Code causes difficulties in its interpretation and in effect leads to contradictions in legal proceedings. A document becomes evidence in the procedural sense only when it is admitted as a source of evidence ${ }^{3}$.

Therefore, a document is any object confirming a given right (e.g. passport, identity card, ticket, cheque, bill of exchange, token or any other object confirming one's entitlement to a benefit) or which - due to its content - constitutes a proof of a right, legal relation (e.g. a copy of a contract) or circumstances of legal significance (e.g. a signature on an attendance list). The definition states as well that a document may be recorded on any medium if it confirms entitlement to a right (e.g. copyright of a computer programme) or if its content constitutes a proof of a right (e.g. a list of stockholders), legal relation (e.g. confirmation of an offer sent by email) or circumstances of legal significance (e.g. the date when a text was written $)^{4}$. The definition of a document in penal law is very wide; a document is not only anything recording intellectual content in writing but also any other objects constituting a proof of law, legal relation or circumstances of legal significance.

To be recognised as a document, the medium where a given idea was recorded is immaterial. A document should express a human thought in the form of declaration of intent or knowledge, i.e. it should carry intellectual content. Due to its content, which constitutes information for an authority conducting legal proceedings, a document is a source of evidence. Documentary evidence in this case consists in reading the intellectual content during a trial. There also are instances when it is not the content but a document's external properties that matter (determining whether a document is genuine or whether it was falsified), which is a case of increased legal protection as defined by art. $115 \S 14$, Penal

3 The binding Polish Penal Code in chapter XIV entitled "Glossary of statutory notions" in art. $115 \S 14$ presents the definition of a document, treating it as an object of legal protection in the cases of crimes against documents defined in chapter XXXIV entitled "Crimes against credibility of documents" in art. 270-277 of the binding Penal Code. Act of 6 June 1997 with subsequent amendments (Dz.U. of 1997 No. 88, item 553 with subsequent amendments).

${ }^{4}$ Kodeks karny. Komentarz, ed. R. Stefański, 2017, Wydanie XVIII, www.sip.legalis.pl, (10.03.2017); Kodeks karny. Komentarz, ed. A. Grześkowiak, K. Wiak 2017, Wydanie 4, www.sip.legalis.pl, (10.03.2017). See also sentence of SN z 3.03.2011 r., V KK 311/10, OSNKW 2011, Nr 6, poz. 52. 
Code. In Polish law of criminal proceedings a document is an expression of thought in writing, irrespectively of the characters used and how they were recorded as long as it includes information significant for the case ${ }^{5}$.

A vital amendment appeared in the Polish civil law, which takes into consideration electronic means of information transfer and a comprehensive definition was introduced into the Civil Code, which radically departs from the traditional understanding of the document as the information recorded in writing and signed. The amendment defines an electronic document as a new and special form of a legal action. In accordance with the new regulation introduced into the Civil Code, it is sufficient to declare intent in the form of document in the way which enables determining the person submitting the declaration. A document is a carrier enabling familiarising oneself with the intent's content ${ }^{6}$, i.e. it is possible to submit the declaration with the use of sound or picture. The definition of document imposes no restrictions on the way of drawing it. A document's content may be revealed in any way (e.g. graphic characters, sound, picture are admissible), recorded on any carrier (e.g. paper, computer files) by any means (e.g. a mobile phone, computer, pen). The limits are only set by the function of a document as evidence, i.e. the possibility of saving and recreating its content ${ }^{7}$.

A document accompanies everyone's life - from a birth certificate to the last will and a death certificate. It confirms certain rights and grants new ones in all spheres of social, political and economic life. Everyone encounters masses of documents, whose number does not decrease despite the development of technology. Paper, invented almost two thousand years ago, still remains the basic material on which documents are drawn. Political and economic transformation resulted in the increase in the number of crimes committed with the use of falsified documents. Technological development requires protection of important public documents. To ensure security and trust to the institutions issuing documents, various measures are taken to protect documents against falsification. In

5 Code of Penal Procedure, Act of 6 June 1997 with subsequent amendments (Dz.U. of 1997 No. 89, item 555 with subsequent amendments).

6 Definition of the document is included in art. $77^{3}$ (Civil Code, Dz.U. 1964 No 16 item. 93, Dz.U. 2017 item 459).

7 Art. $77^{2}$ (Civil Code, Dz.U. 1964 No 16 item 93, Dz.U. 2017 item. 459). 
the age of universal access to electronic means of information transfer, e.g. the Internet, a number of falsifiers equipped with specialist knowledge and professional equipment is growing. Therefore, the issuers of documents, i.e. the subjects entitled to create systems of their protection, are constantly looking for new solutions in this area.

Official documents have a special status in legal circulation. Contrary to many countries, Polish legal system does not define the notion of official document despite a heated debate on the need to introduce such a definition ${ }^{8}$. This need is emphasised in the draft of the act on official documents, prepared by the Ministry of Internal Affairs and Administration". At present an "official document" is not a legal notion. A definition of an official document may be found in the draft of the act on public documents of 27 November 2016, where art. 2(2) states that an official document is a document protected against falsification, which is used to identify people, objects or to confirm the legal status or rights of their bearers ${ }^{10}$.

Official documents guarantee the security of legal and financial transactions. They are a proof of acts in law and circumstances of legal significance, therefore, to be credible they must be protected. On the other hand, there are no perfect security measures preventing falsification. An essential role in combating falsification of documents is played by experts in document examination, who possess specialist knowledge necessary to identify the features of a questioned document and confirm its authenticity. Protection of documents (i.e. banknotes, identity cards, vehicle certificates, securities, insurance certificates, etc.) has to meet certain requirements to be reliable, i.e. to be resistant to mechanical, physical and chemical factors. It has to the greatest possible degree hinder any efforts made by falsifiers. Because one security measure is not sufficient,

${ }^{8}$ A. Lenart, "Rola zabezpieczeń stosowanych w dokumentach publicznych. Weryfikacja zabezpieczeń i kontrola autentyczności dowodów osobistych", Wiedza Prawni$c z a$, no. 3/2008, p. 32-33. www.wiedzaprawnicza.pl (10.02.2017). Cf. W. Brzęk, M. Goc, "Znaczenie uregulowań prawnych w aspekcie produkcji dokumentów", Człowiek i Dokumenty, no. 3 (October-December 2006); Polska Wytwórnia Papierów Wartościowych S.A. w Warszawie, www.czlowiekidokumenty.pl (20.03.2017).

9 www.mnisw.gov.pl, retrieved: 30.03.2017.

10 The draft is available on the website of the Government Centre of Legislation (Rządowe Centrum Legislacji), www.legislacja.rcl.gov.pl (31.03.2017). 
several are used. A falsified document is made in another technique and from other materials than a genuine one, imitating the latter more or less successfully. The phenomenon of falsification may be minimised by the use of many different security measures discouraging potential falsifiers, making sure that the cost incurred when attempting a falsification is too high to make an attempt at falsification viable. Documents have to perform their function for several years, therefore their issuers introduce experimental security measures, very difficult to produce and introduce, in an attempt to get ahead of falsifiers. Obviously, absolute protection is impossible and the scope of falsification may only be restricted by introducing not one but a few security measures. Contemporary range of the measures is very wide; their number and type used in each particular case depends on the importance, purpose of a document, its form, i.e. whether it is a booklet (e.g. a passport), a card (e.g. driving licence, identity card, banknote) as well as frequency, way and circumstances in which a document is used ${ }^{11}$.

An important criterion for selecting a security measure is the technology of introducing it, i.e. whether it is introduced during the process of producing paper or when a document is printed on paper; there also are the so-called special security devices — introduced during a separate technological process. Emphasising a significant role of all the criteria listed above, special attention should be paid to the latter - the technology of introduction. The security measures introduced during the process of production of paper are divided into two groups: secret and visible. The former includes mainly chemical measures. Certain chemical compounds of paper cause the change of colour in the places where counterfeiting is attempted. Some compounds may only be detected in laboratory conditions, after a document is burnt. Another security measure from this group is optical whitening agents, i.e. chemical compounds and fibres containing dyes activated by electromagnetic radiation of a particular wavelength. A specific type of security measures from this group is the so-called identifiers. The paper containing them changes colour

11 T. Kołecki, Technicznokryminalistyczne badania autentyczności dokumentów publicznych, Poznań 2002, pp. 6-20. Also R. Cieśla, "Protection of Documents and Possibilities of their Verification (Part I)", [in:] Document. Various Specifications, Z. Kegel (ed.), no. 7/2003, Wrocław 2003, pp. 83-89. 
after its surface is treated with a particular compound, the so-called developer. The induced change of colour may be temporary or permanent. Metals in various forms are added to paper, which emit signals when fed into readers equipped with detectors. The basic function of chemical measures is protecting a document against counterfeiting, i.e. preventing introducing changes to parts or the whole of a document by introducing false inscription or stamps. Paper, or rather the composition of the raw material from which it was produced, is also a kind of secret protection. Kept in secret by the producer, it constitutes an insurmountable barrier for a falsifier when selecting the material to be used in the production of a fake document ${ }^{12}$.

Security measures include, e.g. watermarks, colour fibres, security strips, three-dimensional strips ${ }^{13}$, microperforations, use of synthetic and semi-synthetic paper ${ }^{14}$.

The way of producing and forming a watermark has not changed for hundreds of years ${ }^{15}$, only the tools and material used at various stages of the production process have due to the development of technology. In practical terms a watermark cannot be falsified, because this would require repeating the whole process of producing paper. Therefore, falsifiers look for other solutions, producing its imitations. A watermark is seen when looking at paper against light and it is usually used in producing securities or high quality paper. Its characteristic feature is depth,

12 D. Mierzejewski, M. Rogalska, M. Rosiak, "Papiery zabezpieczone i specjalne produkowane w PWPW”, Człowiek i Dokumenty, no. 42, (July-September) 2016, pp. 39-45.

13 Cf. Banknotes of the denominations of 1000 SEK, 50 GPB, 200 PLN.

14 An interesting and innovative solution is the Laser Engravable Anti-counterfeiting Paper $\left(\right.$ LEAP $\left.{ }^{\circ}\right)$ invented and patented by the Polish Security Printing Works S.A. in Warsaw. It is produced from special paper pulp and a coating solution, thanks to which a clear picture may be produced with laser etching without the need to laminate it with plastic foil. So far laser etching has been used for polycarbon- or polycarbon/paper-based documents. The composition of the new paper enables etching on its surface and within the paper pulp, which produces an interesting effect of enhancing a picture seen against the light, similar to a watermark. The images can also be felt with fingers. All security measures used for regular paper can be applied here (watermark, chemical security measures, security strips and fibres). The paper is compatible with the printing and personalisation techniques used in production of documents. www.pwpw.pl, (30.03.2017).

15 S. Jakucewicz, S. Khadzhynova, Sposoby zabezpieczania dokumentów, Łódź 2015, p. 12 ff.

Nowa Kodyfikacja Prawa Karnego 44, 2017

(C) for this edition by CNS 
which gives the effect of three-dimensionality. Colour fibres are made from various materials and display various features. They are usually made from silk, wool, flax or synthetic materials, introduced at the stage of production of paper in a strictly determined quantity. They may be randomly or regularly distributed in paper pulp. Apart from the colour they are luminescent, emitting light in, e.g. ultraviolet radiation. Fibres are embedded at the stage of production of paper and as a result they are randomly distributed. Their characteristic feature is that they cannot be removed without interfering with the structure of paper. Another security measure is microscopic disks made from plastic embedded in paper pulp in the same way as fibres, and displaying similar features. They may be embedded in regular patterns in paper and usually they assume the form of a strip on a document's margin, preventing photocopying or scanning, because on a copy they appear as dark spots ${ }^{16}$.

Security strips are made from plastic; they may be metal-plated or holographic. They are embedded in paper at the stage of its production, running along the paper web. They may also be covered with a luminescent substance, emitting light in ultraviolet radiation. Currently intelligent strips are used, which may carry coded signals induced by electromagnetic waves; they may also display magnetic sensitivity. The strip usually runs across a banknote; it is visible against light and can be felt with fingers, even though it is embedded in paper. In some cases it is visible on the surface as a broken strip carrying a hologram, which constitutes an additional security measure against copying. Security strips perform two functions: one is concerned with optical properties, the other with automatic detection. One strip may carry macro-features visible to everyone and micro-features accessible only for specialists. A strip may assume the form of a three-dimensional picture seen as a whole or only in parts on a document's surface. In practice additional options may be used, such as multi-colour coating of a precisely determined sequence of colours, patterns or fluorescent coating. If strips are magnetised, by forming a pattern from magnetic material along a strip, a coded strip is produced. This security measure has been used for years, e.g. in banknotes in the form of polyester magnetic strips embedded in paper. Both magnetic

${ }^{16}$ Ibid., p. 12 ff. 
and metallic strips are of no greater consequence for most users, because they are visible as a dark line difficult to distinguish from a similar line on a fake document. Microperforation and perforation are usually used in booklets and synthetic documents. A document is perforated with a laser or by mechanical means, making holes, which — visible for the naked eye - carry information. The perforated pattern is visible in reflected light and against it. Relative to the requirements, the angle and size of the perforations may vary. Microperforation is a variant of perforation, so precise that it has to be made only with a laser. Perforated holes made at the right angle have identical sizes. Microperforation is a very good security measure, used in banknotes and identity cards in some countries. Due to the great precision of their making and microscopic diameter of the holes, it is best visible against the light or under a microscope.

While discussing the use of synthetic paper as yet another security measure, a dynamically developing technology of polycarbonate use must be mentioned ${ }^{17}$. Paper may be laminated with layers of polycarbonate or it may be made exclusively from polycarbonate fibres. Several European countries issue documents made from synthetic paper, such as passports, identity cards, driving licences. Polycarbonate documents are stratified structures, whose core is constituted by paper or white polycarbonate with graphic elements, including such security measures as microprint, fluorescent paints or multi-colour etching. The core is laminated with layers of transparent polycarbonate. Personal data and a photograph are made with laser beams of various diameters on the border between two layers or in both layers of polycarbonate. Treated with the laser light polycarbonate particles change into particles of carbon, forming microbubbles in the polycarbonate mass, which renders an impression of convexity. Polycarbonate technology enables producing black and white images, made with a laser, producing a much better quality picture than it is possible with other techniques. A polycarbonate document may be additionally protected by applying optically changeable patterns on its surface, i.e. optically changeable paints or holograms. In the case of documents made exclusively from polycarbonates, microprocessors may

17 Cf. footnote 9. 
be also used. Polycarbonates are very resistant to humidity and temperature changes ${ }^{18}$.

A hologram is a very interesting - and still underestimated special security measure ${ }^{19}$. It is made in special material of a very high resolution. The physical and chemical processes involved in a hologram differ completely from those traditionally used in typography and papermaking; therefore a falsifier must have be an expert in new areas, such as optics. A holographic picture is the product of diffractive light diffusion on very delicate spatial structures and an effect of diffractive mixing of waves in space ${ }^{20}$.

The spectrum of implemented security measures has to be adapted to the nature and purpose of a document. Their number varies from several to several dozen, constituting a system which has to include security measures that can be verified on the four levels mentioned above and considered as sufficient by the issuer.

Biometrics is increasingly more frequently used in protecting documents. It consists in automatic identification of a person on the basis of measurements of biological features, either static, such as the appearance of the face or fingerprints, or dynamic - dynamics of walking or writing a signature. Even though these methods of confirming identity have had a long tradition (in European culture documents have always been signed while most paper documents contain photographs), automatic methods still cause anxiety and are less commonly used than the former ${ }^{21}$. This type of security measure enables even more efficient identification of a document with its bearer. The use of biometric data requires a scanner or another device for collecting biometric features, computer programmes to process the data and a database containing samples collected during the process of producing a document. Biometrics is used to identify and

18 R. Cieśla, "Protection of documents and possibilities of their verification. Part II", [in:] Document. Various specifications, Z. Kegel (ed.), no. 8/2004, pp. 103-104.

19 D. Śledziewski, Dowód osobisty - zabezpieczenia stwierdzające autentyczność dokumentu, Materiały dydaktyczne, Zakład Szkoleń Specjalnych, Centrum Szkolenia Policji, Legionowo 2013, p. 9.

20 Cf. R. Cieśla, "Protection of documents and possibilities of their verification. Part II", [in:] Document. Various specifications, Z. Kegel (ed.), no. 8/2004, pp. 105-106.

21 S. Jakucewicz, S. Khadzhynova, Sposoby zabezpieczania dokumentów, Łódź 2015, pp. 111-112. 
verify identity of a person using a document. Identification consists in determining who a given person is and verification consists in determining whether a given person is who he or she says they are. In both cases a person's biometric data are collected and compared with those in the database of samples collected when a document was issued. Biometric features used in creating security systems are fingerprints, image of a face, geometry of the palm, arrangement of palm's blood vessels, an iris, recording of the voice, DNA, rhythm of typing, the way of walking or even the shape of the ear ${ }^{22}$. Yet another biometric technique enables decoding a person's body geometry with the use of special screening equipment. However, such systems cause debate due to very serious interference with privacy. Yet, the future is difficult to predict, especially in the context of recent events in the Middle East ${ }^{23}$, terrorist attacks and the unprecedented scale of migration recently experienced in Europe ${ }^{24}$.

Some of the biometric parameters mentioned above are used as protective measures in documents. It has to be emphasised that no biometric technique in itself is perfect and its implementation in documents is not and probably will not be a perfect security measure protecting against falsification. Therefore, to increase the security level, the most frequently used solution is the implementation of two, three or more biometric security measures in a document (e.g. biometrics of the face, fingerprints, signature), thus decreasing the risk of its being falsified.

It is worth noting that Polish law does not define a biometric document; however, it is universally recognised that it is a document carrying

22 Ibid., pp. 111-112; M. Michalak-Tomaszewska, Prawne i kryminalistyczne aspekty wykorzystania technologii biometrycznej w Polsce, Warszawa 2015, pp. 58-81. Biometric protective measures were used in the electronic layer of identity cards of some countries, e.g. Italy, www.gemalto.com/govt/customer-cases/new-national-identity-cardfor-italy (retrieved 31.03.2017). A. Bodnar, J. Michalski, "Dokument biometryczny a prawa człowieka”, [in:] E. Gruza (ed.), Dokumenty we współczesnym prawie, Warsaw 2009, pp. 52-54.

23 Especially since June 2014, K. Strachota, "Bliski Wschód w cieniu Państwa Islamskiego”, wyd. Ośrodek Studiów Wschodnich im. M. Karpia, Punkt Widzenia no 52/2015, Warszawa 2015, pp. 8 ff.

24 Cf. recent terrorist attacks in Paris (November 2015), Brussels (March 2016), Nice (July 2016), Berlin (December 2016), London (March 2017), Stockholm (April 2017). 
biometric identifiers used in the process of identifying a person or verifying his or her identity. The first document in Poland to have acquired the status of a biometric one is the passport ${ }^{25}$ issued in accordance with the EU Council Regulation no 2252/2004 on standards for security features and biometrics in passports and travel documents issued by Member States $^{26}$. The regulation states that apart from traditional security measures, a European Union citizen's passport should include a biometric photograph and a chip with recorded fingertips of its bearer. The regulation does not provide details as to the use of biometric technology in a passport, which does not help individual member states to implement technical and legal regulation concerning new security measures in the protection of documents ${ }^{27}$.

The applied system of security measures has to take into account technological progress, adapting its achievements, but it also has to take into consideration the fact that the very same progress offers falsifiers access to advanced equipment enabling effective falsification of the security measures used in genuine documents. The use of modern technology combined with biometric data in protecting documents is the right solution as this hinders falsifiers' efforts, at least temporarily. Producers and issuers of documents must be aware that there are no perfect security measures and must look for new and effective solutions in this area. Hopefully, the Polish identity card soon to be introduced into circulation will be sufficiently protected and at least for a while it will hinder falsifiers in

${ }^{25}$ Act of 13 July 2006 on passports, Dz.U. no 2006, No 143 item1027 with subsequent amendments.

${ }^{26}$ Council Regulation (EC) No 2252/2004 of 13 December 2004 on standards for security features and biometrics in passports and travel documents issued by Member States, and Document 9303 of the International Civil Aviation Organisation (ICAO), http://eur-lex.europa.eu (31 March 2017).

27 A document which contains biometric features is also a travel document as stipulated the Geneva Convention (Dz.U. 1991, item 119, item 515 and 516). Cf. M. Michalak-Tomaszewska, Prawne i kryminalistyczne aspekty wykorzystania technologii biometrycznej w Polsce, Warszawa 2015, pp. 59-60. A document which will contain biometric identifiers in the electronic stratum will also be the Polish identity card; its introduction is planned for 2019. Introduction of an electronic identity card is also planned. Cf. R. Lewandowski, "Analiza Koncepcji wdrożenia polskiego dowodu osobistego z warstwą elektroniczną", Przegląd Bezpieczeństwa Wewnętrznego, no 16 (9) 2017, pp. 215-226. 
plying their trade ${ }^{28}$. In creating an effective system of security measures the costs involved are also very important. Resigning from the use of certain measures may result in an increased number of fake documents, whose presence in public circulation depends primarily on the needs and aims of criminal activity in various areas of social and economic life.

\section{References}

Bodnar A., Michalski J., Dokument biometryczny a prawa czlowieka, [in:] E. Gruza (ed.), Dokumenty we wspótczesnym prawie, Warszawa 2009, pp. 52-54.

Cieśla R., "Protection of Documents and Possibilities of their Verification (Part I)", [in:] Z. Kegel (ed.), Document. Various Specifications, no. 7, Wrocław 2003, pp. 83-89.

Cieśla R., "Protecttion of Documents and Possibilities of their Verification (Part II)", [in:]

Z. Kegel (ed.), Document. Various Specifications, no. 8, Wrocław 2004, pp. 103-106.

Cieśla R., Technical Examination of Documents. Within the Scope of Polish Evidence Law, Wrocław 2006, pp. 34-52.

Civil Code (Dz.U. 1964 No 16, item. 93, Dz.U. 2017, item 459).

Council Regulation (EC) No 2252/2004.

Dz.U. 2006 No 143, item.1027.

Geneva Convention (Dz.U. 1991, item 119, item 515 and 516).

Jakucewicz S., Khadzhynova S., Sposoby zabezpieczania dokumentów, Łódź 2015, pp. 111112.

Koźmiński L., Dokument jako ślad kryminalistyczny, Piła 2010, p. 6.

Kołecki T., Technicznokryminalistyczne badania autentyczności dokumentów publicznych, Poznań 2002, pp. 6-20.

Lenart A., "Rola zabezpieczeń stosowanych w dokumentach publicznych. Weryfikacja zabezpieczeń i kontrola autentyczności dowodów osobistych", Wiedza Prawnicza 2008, no. 3, pp. 32-33.

Lewandowski R., "Analiza koncepcji wdrożenia polskiego dowodu osobistego z warstwą elektroniczną", Przegląd Bezpieczeństwa Wewnętrznego 2017, no. 16(9), pp. 215226.

Michalak-Tomaszewska M., Prawne i kryminalistyczne aspekty wykorzystania technologii biometrycznej w Polsce, Warszawa 2015, pp. 58-81.

Mierzejewski D., Rogalska M., Rosiak M., "Papiery zabezpieczone i specjalne produkowane w PWPW", Czlowiek i Dokumenty 2016, no. 42, pp. 39-45.

Polish Penal Code (Dz.U. 1997 No 88, item 553).

Polish Penal Procedure (Dz.U. 1997 No 89, item 555).

28 Cf. Sz. Ruman, "E-dowód. Państwo Usługowe i Cyfrowa Suwerenność", Człowiek i Dokumenty, no. 42 (July-September) 2016, Warszawa 2016, pp. 9-14.

Nowa Kodyfikacja Prawa Karnego 44, 2017

(C) for this edition by CNS 
Ruman Sz., "E-dowód. Państwo Usługowe i Cyfrowa Suwerenność”, Człowiek i Dokumenty 2016, no. 42, pp. 9-14.

SN, 3.03.2011, VK 311/10, OSNKW 2011, No 6, item 52.

Strachota K., "Bliski Wschód w cieniu Państwa Islamskiego", Punkt Widzenia 2015, no. 52, pp. $8 \mathrm{ff}$.

Śledziewski D., Dowód osobisty - zabezpieczenia stwierdzajace autentyczność dokumentu. Materiały dydaktyczne, Zakład Szkoleń Specjalnych, Centrum Szkolenia

Policji, Legionowo 2013, p. 9.

www.gemalto.com.

www.mnisw.gov.pl.

www.pwpw.pl.

\section{Summary}

Evolution of political and economic transformation has to a considerable degree contributed to the increase of crimes committed with fake documents. Development of civilisation and technological progress necessitate protection of public documents. To ensure security and trust to the institutions issuing documents their producers and issuers use various security measures to protect them against falsification. Combination of advanced technologies with biometric identifiers is a necessary solution. Implementation of advanced security measures should, at least for a certain period of time, hinder production of falsified documents. Producers and issuers of secured documents should persist in their efforts to look for new and effective technical and legal solutions in protecting documents. In this context legislative work on creating a comprehensive legal act on public documents in Poland is a necessary solution.

Keywords: document, evidence, public document, official document, protection, research, biometrics, falsification, forgery, counterfeiting. 